\title{
Consumption of Alcohol in Croatian Social Reality \\ Alcohol as Part of Interaction Ritual Chain
}

\author{
Erik Brezovec \\ University Department of Croatian Studies, Zagreb, Croatia
}

\begin{abstract}
Article is exploring the phenomena of interactional ritual chains of everyday life. Primarily, focus is on social interaction and integration of an individual in Croatia. We are going to use the basic premises of micro-sociological analysis of which in the center of attention is the theory of Randal Collins, symbolic interactionism and phenomenology. According to mentioned aspects, the paper analyzes the usage of alcohol in Croatia, which is basically traditionally organized. The main premise of this work is that alcohol is one of the symbols of forming interaction ritual chain of everyday life. Alcohol by its own definition poses a great symbolic power and it is an inevitable factor of ritual chains of everyday life. Alcohol is a part of traditional values so it is almost impossible to exclude it from everyday life.
\end{abstract}

Keywords: alcohol, alcoholism, ritual chain, tradition, symbol, integration, interaction

Copyright @ 2017 KBCSM, Zagreb

e-mail: alcoholism.kbcsm@gmail.com•www.http//hrcak.srce.hr/acoholism

\section{Introduction}

In anthropology, rituals can be seen as a formal action directed at social pattern which makes cohesion of the group possible. This cohesion primarily uses symbols to integrate a large group of people with different agendas and personalities. We may consider rituals as dominant phenomena in the system of religion, but rituals are present every time when interaction and after it integration happens.

Correspondence to: Erik Brezovec

University Department of Croatian Studies, Borongajska cesta 83d, Zagreb, Croatia

e-mail: erik.brezovec1@gmail.com
Primary aspect of rituals is the separation of sacred and profane. Whereas profane often includes every corner of everyday life, sacred entities are strictly excluded from it. Sacred entities or objects are the source of admiration and respect.

However in sociology, rituals are considered as a continuous form of interaction. Every form of interaction which is considered formal and strict and followed by rules of any kind has rituals as its basic component. These rituals are not manifested to individuals. An individual latently uses rituals of everyday life as their basic social capability. For example, we can take a handshake. Two friends can have their own handshake. This 
handshake cannot be understandable to an outsider, but he can clearly see that this is a handshake of some kind. Even the necessity of having a handshake can put their handshake in the frame of society. Modification generated by their intimacy and the need of excluding other members of the society did not remove basics of the ritual in handshake. Formal handshake on the other hand has strict rules and cannot be modified. However that kind of a handshake does not necessarily possess emotional significance. Strength of ritual depends highly on the individual level of significance that he puts into the ritual. That fact leads us to the conclusion that rituals are primarily the domain of micro-sociological analyses. Some authors conclude that interaction ritual chains are the very key of micro-sociology [1].

\section{Methods}

In this paper we are going to use the theoretical concept of "Interaction ritual chains" by Randal Collins accompanied with phenomenology of Berger and Luckmann. First of all, interaction ritual chains have their components which allow them to integrate a large number of individuals into the specific group. Without some of the basic components rituals do not have the legitimacy to act and regulate behaviour of the society. An individual and a group of people that he is a part of, have to have an emotional connection to the ritual process. When the emotional connection is established, group is making a collective focus of attention to some object or entity. This focus of attention is of the utmost importance for this paper. For the ritual to become a legitimate cohesion maker in some society, it has to have four main components. First of all, two or more people have to be present in the interaction. People in this interaction must have significant influence on each other. The second criterion is to make a distinction from the others, who are not part of the group, from those who do not pay respect neither possess emotional connection to a certain ritual. As we have mentioned before, one of the premises of interaction ritual is attention and focus of the group toward an object and entity. Attention and focus is shared through communication. At the very end, the group share emotional connection which is an integrating emotional connection toward ritual from each individual into an organised social connection. Through this chain, rituals are historically strong, getting the status of values or even norms in specific social context [2].

When we consider the term ritual it is important to add that it is mainly a social event which identifies a certain group of individuals. Rituals are also an important part of tradition. When we discuss rituals it is important to mention the importance of symbols for rituals. In the interaction ritual chain symbols are not well manifested as it is the case with more formal rituals (for example religious rituals). However, interaction rituals are latently rich with symbolism and meaning. We can define a symbol as everything that has meaning for a group and along the group for an individual. Symbols are often considered sacred which automatically divide them from profane everyday life but in the interaction rituals, these sacred symbols are connected to everyday life, they make everyday life meaningful and along with that they make cohesive interaction possible. Symbols, from that point of view, are playing a crucial role in making one ritual more emotional than the routine one. That significance given by the 
symbol makes one ritual stronger in the social system $[3,4]$.

However, rules and order also have an important role in the ritual chain, the role that ascends action. Improvisations cannot be made in order for the ritual to be legitimate. Improvisation is an action which is not part of a ritual, but only in the context of more formal ritual chain. If we go back to example with a handshake we can see that handshake as a ritual survives but on the action level it is submitted to a certain point of improvisation. Improvisation in that case does not exclude the power of the handshake ritual [5].

\section{Alcohol as a symbol in the structural context}

Symbols are, as we saw earlier in the paper, crucial for the significance of a ritual, especially for the rituals of everyday life. The symbol gives the event or entity a certain emotional connection with the people. In this paper we are going to look at alcohol as one of these symbols for certain ritual chains in Croatian social reality. We are going to examine the use of alcohol through few examples of interaction in the rituals of everyday life.

Before we continue with examples it is important to point out some important contextual facts which made alcohol significant for the stock of knowledge in Croatian reality.

First of all, it is important to add that Croatian geopolitical context is primarily the one that is included in the Western civilisation world. Historically, the use of alcohol has been considered as the customary part of everyday life. Until the 18th and 19th century drinking a large amount of alcohol was not considered deviant, neither anyone thought of alcohol as a potential addiction supplement. According to the pointed fact, rituals and everyday routine have built a stock of knowledge (historically) which puts alcohol deeply into the praxis. Berger and Luckmann place the focus on action which is partially determined by the stock of knowledge which is historically constructed through the past agency. If some of the aspects of an agency get their own place in the stock of knowledge, it becomes a value inside one reality which is reality per excellance (reality of everyday life). Once this phenomenon gets its own place inside this reality, it can hardly be pushed away and it is hard to define it as unwanted or deviant $[6,8]$.

One connection made alcohol an even stronger factor in the social reality. Christianity and alcohol are ritually connected. The process of turning wine into Jesus Christ's blood during a ritual certainly gives alcohol a lot of significance. In this example the wine represents Jesus Christ's blood and along with that becomes a powerful symbol.

Croatian national identity is very much in correlation with a confessional identity of the Roman Catholic identity. Taking that into consideration, alcohol has a lot of power as a symbol in Croatian society. Jesus turned water into wine, and consequently gave his permission for the consumption. Croatian reality adopted specific values of the Western civilization.

\section{Alcohol in Croatian reality}

As we mentioned earlier, alcohol is widely present in the reality of everyday life in Croatia. It is spread across almost every social field. Alcohol is being used and has its symbolic meaning throughout the reality of different social classes of people. Alcohol is consumed regardless of the socioeconomic status. It is one of the typical and everyday symbols of Croatian life. 


\section{Alcohol and cultural sphere}

Cultural field of interaction in Croatia is a field with the importance of alcohol. The best way to describe its influence is through an example in north-west Croatia. In rural parts of Croatia there is a large cultural capital gathered around cultural clubs. They are direct promoters of tradition and culture around the social reality. Members of the club are highly integrated and "wear the colors of their past" with pride. However, one of the inevitable factors and symbols in the club is alcohol which follows the representation of the culture and tradition they celebrate. Celebration is organised in a traditional manner and it always includes high alcohol consumption. Celebration without celebration has no emotional significance and therefore cannot integrate members of the club with a pure tradition and cultural club goals. The ritual of celebration in interaction ritual chain uses alcohol to integrate and connect members on the emotional level.

This type of celebration presents a problem for "non-drinkers". It is not constant and it is not manifest for members of a club to exclude non-drinkers from their ritual, but it is a fact that they achieve integration harder. There were cases when non-drinkers quit their club because they considered they were not having a good time. Alcohol in traditional cultural clubs is represented as a symbol of integration, but it also creates a distinction "insider-outsider", which is one of the premises of interactional ritual chain.

\section{Alcohol and socialization}

Socialization is one of the most important factors for the reproduction of the system or specific society. Literally, socialization is a process of making something social. Repro- ducing a structure with a stock of knowledge given to every individual throughout the socialization, practices are born which slowly on the historical basis become tradition [9].

Socialization in the Croatian society is filled with alcohol symbols. From a young age, children are given a taste of alcohol beverages. Parents, relatives or reliable people control the tasting.. Situations, when a child wants more or demands more alcohol are followed by the amusement of the people present at that moment. Obviously, this course of action encourages the child, and gives him an image of the importance of alcohol for his reality and habitus.

Influence of the significant other plays the most important role for a proper socialization in the society. If a child is introduced to alcohol in a way of admiring it or as a part of his life there is a bigger risk of addiction in the future.

Cultural determination toward alcohol is created by the process of socialization, which is generated by the tradition and the stock of knowledge. It is not whether you want alcohol in your life or not. Alcohol is part of your reality. Deep connection in Croatian society and reality toward alcohol gives it a ritual importance which is hard to avoid by the individual who is part of the society.

\section{Alcoholism and Croatian society}

After defining the position of alcohol in Croatian social reality, it is important to mention the social position toward alcoholism. Alcoholism is one of the most spread chronic diseases and it is a serious social and medical problem of contemporary age. An alcoholic is a person who drinks long term and is addicted to alcohol in physical or psychical aspect. Alcohol, in the body of an alcohol- 
ic, generates serious medical conditions. An alcoholic often experiences problems in the social life or interaction. Alcoholism can also generate other forms of social pathology, for example; domestic violence, or deviance in the workplace [10].

Nevertheless, the consumption of alcohol carries a risk of adverse health and social consequences related to its intoxicating, toxic and dependence-producing properties. In addition to the chronic diseases that may develop in those who drink large amounts of alcohol over a number of years, alcohol use is also associated with an increased risk of acute bealth conditions, such as injuries, including from traffic accidents. [11]

Primarily, we are going to analyse social deviation which alcoholism produces. Alcoholism is a form of social pathology which influences the capability of an individual's role in the society. A person with an alcohol addiction cannot integrate properly in the social domain of life. This disintegration creates the lack of meaning and belonging, which can generate other forms of deviance. According to that, alcoholism is a serious social problem and it has to be treated as such. However, social understanding of alcoholism is that it is an addiction and a disease. Discourse of alcohol as sickness occurred at the beginning of the 19th century. This reality was formed, as Foucault claims, as a new paradigm of madness which for its own therapy had moral treatment. He claims that new discourse was generated by the new economic, political power of social elite which created a new paradigm in the social reality. This new discourse mixed itself, and forced itself into the reality of everyday life. The problem is that reality of everyday life was already formed with already known tradition in which alcohol had very a important role as a symbol in the interaction ritual chain. Associating alcohol discourse as dangerous with the traditional discourse of alcohol, created a specific type of relationship between alcohol and the society. This relation can be manifested in a society that respects tradition [12].

Double standards in Croatian society made the complex reality in which alcohol is an important part, but alcoholism itself is considered highly deviant. However, alcoholism as deviancies treated differently by the intensity of addiction. Alcoholism in traditional Croatian reality is not considered a problem, as long as an individual can remain functional in the society. The moment an individual becomes dysfunctional in the society he is marked as deviant and alcoholic. Alcoholism is not a disease and addiction as long as an alcoholic does not break standard reality. This perspective is legitimate in the macro context, but in the micro perspective view of this reality, alcoholism of that kind is dangerous. To tolerate a social functional alcoholic is to look away from the domestic problems, and micro problems which alcoholism generates.

Traditional view of alcoholism in Croatia is influenced by the discourse of alcohol as part of everyday life. Individuals take action according to the type of the alcohol present in the Croatian society. Going out with friends is often in correlation with heavy drinking. Long term alcohol abuse can be considered as alcoholism, but social reality and the legitimacy of alcohol prevent it from becoming one.

\section{Discussion}

Croatian reality is rich with symbols and rituals which include the use of alcohol. Objectification of alcoholism is not manifested only throughout consumption but also through the language and verbal interaction which gives alcohol an emotional, sacred di- 
mension. Consequently, alcohol has become a strong symbol and a permanent part of tradition. In some cases of interaction alcohol can also be an integrative factor. Croatian reality has been manifested through the interaction ritual chains which are basically, not only tolerating alcohol but also giving it the significant role in reality. Exclusion of the people who do not tolerate this position of alcohol is also a fact. In some cases "nondrinkers" are excluded from some of the activities purely because they do not consume alcohol. Non-drinkers lack the integration role which alcohol gives at a certain moment.

Alcohol in our paper is not a ritual of the Croatian society but it is an important part of everyday life and serves as a symbol in the larger scale of rituals, along with other variables. Alcohol use in Croatia, as a symbol or as consumption, is present in structural and interaction aspects of social life. On structural basis, alcohol serves as an integrative factor and sacralization inside social rituals. Alcohol also enables a larger emotional connection to the structure.

\section{References}

1. Abercrombie N, Hill S, Turner B. Rječnik sociologije. Zagreb: Jesenski i Turk; 2008. p. 317.

2. Collins R. Interaction Ritual Chain. New York: Princeton University; 2005. p. 13-48.

3. Čapo-Ž́megać J. Hrvatski uskrsni običaji. Zagreb: Golden Marketing; 1997. p. 8.

4. Mach Z. "Continuity and Change in Political Ritual: May Day in Poland" In J. Boissevain editor. Revitalizing European Rituals. London and New York: Routledge; 1992. p. 43-61.

5. Mišetić A. Gradski rituali: retradicionalizacija društvenog života u hrvatskim gradovima nakon
Legitimacy of alcohol from the aspect of tradition made the complex social reality which included contemporary discourse of alcoholism as an addiction and as a disease and with alcohol as potentially dangerous. This inclusion created a discourse which tolerates alcohol and the alcoholism as long as an individual is functional. This reality however poses a threat to the micro solidarity, as an alcoholic can be partially functional in the larger structural context but in the interaction and domestic sphere of social life there is a danger of alcohol as generator of certain types of social pathology such as domestic violence.

\section{Acknowledgments}

None

\section{Conflict of interest}

None to declare
1990. Zagreb: Hrvatska sveučilišna naklada. 2004. p. 15-43.

6. Huntington S. Sukob civilizacija i preustroj svjetskog poretka. Zagreb: Izvori; 1998.

7. Levine HG. "The discovery of addiction: changing conceptions of habitual drunkenness in America". J Stud Alcohol. 1978;15:493-506.

8. Berger P, Luckmann N. Socijalna kontrukcija zbilje: rasprava o sociologiji znanja. Zagreb: Naprijed; 1992.

9. Pesch H. "Socijalizacija". Obnovljeni život : časopis za filozofiju i religijske znanosti. 1924;5:10-18. 
10. Rapić M, Vrcić Keglević M. "Alcoholism - forgotten diagnosis in family practice". Medicina familiaris Croatica : journal of the Croatian Association of Family medicine. 2015;22:25-32.
11. World Health Organization Health topic: Alcohol. Avaliable from: http://www.who.int/topics/alcohol_drinking/en/ [Accessed $23^{\text {rd }}$ June 2016].

12. Foucault M. The Birth Of The Clinic; An Archaeology Of Medical Perception. New York:Vintage; 1975. p. 199.

\section{Uporaba alkohola u hrvatskoj socijalnoj stvarnosti Alkohol kao dio interakcijskog ritualnog lanca}

Sažetak- Rad polazi od analize fenomena interakcijskih ritualnih lanaca svakodnevnog života. Prvenstveno se stavlja fokus na opservaciju socijalnog djelovanja individue unutar hrvatskog društva, kao i procese njegove integracije u isto društvo. U radu će se koristiti osnove mikrosociološkog pristupa fenomenima u centru kojih će biti teorija Randal Collinsa, simboličkog interakcionizma i fenomenologije. Sukladno navedenom, u radu se analizira upotreba alkohola u socijalnoj stvarnosti Hrvatske koja je prvenstveno usmjerena tradicijski prema svijetu života. Osnovna premisa rada jest alkohol kao simbol interakcijskih rituala svakodnevice. Alkohol u tom smislu karakterizira visoka razina simboličke moći te je kao takav neizbježan faktor stvaranja ritualnih oblika djelovanja unutar društvene akcije. Alkohol je dio tradicije, a samim time i vrijednosti unutar određenog društva te ga je kao takvog nemoguće isključiti iz svakodnevnog života.

Ključne riječi: alkohol, alkoholizam, ritualni lanac, tradicija, simbol, integracija, interakcija 